IJIS Indonesian Journal on Information System

\title{
APLIKASI UJIAN SEMESTER BERBASIS WEB PADA PRODI TEKNIK INFORMATIKA UNIVERSITAS MUHAMMADIYAH MALUKU UTARA
}

\section{EXAMINATION OF WEB-BASED APPLICATIONS IN DEPARTMENT OF INFORMATICS ENGINEERING AT UNIVERSITY MUHAMMADIYAH NORTH MALUKU}

\author{
Rizky Ambarita \\ Fakultas Teknik, Program Studi Teknik Informatika \\ Universitas Muhammadiyah Maluku Utara \\ rizkyambarita14@gmail.com
}

\begin{abstract}
Abstrak
Prodi Teknik Informatika universitas Muhammadiyah Maluku Utara masih menggunakan sistem ujian manual atau tidak menggunakan koneksi jaringan. untuk itu penulis mengajukan sebuah Aplikasi Ujian yang berbasis Web dengan menggunakan koneksi antar jaringan yaitu dengan sistem client-server. Sistem client server adalah sebuah sistem pembagian kerja antara sistem dan client yang mengakses server dalam suatu jaringan. Sistem yang dirancang menggunakan software Joomla, Penilitian ini terdiri Wawancara, Pengamatan, Studi Pustaka. Hasil dari penilitian ini diharapkan Aplikasi ini dapat difungsikan untuk mempermudah Dosen dalam memberikan Ujian Semester, menambah pengetahuan dan juga membuat ujian berjalan lebih praktis.
\end{abstract}

Kata Kunci : Aplikasi, Ujian, Web

Abstract

Informatics Engineering Department of the Muhammadiyah University of North Maluku are still using the manual test system or not using the network connection. to the authors propose a test based Web applications using inter-network connection is the client-server system. The client-server system is a system of division of labor between the system and the client access server in a network. A system that is designed to use the software Joomla, This research comprised interviews, observation, Study Library. The results of this research are expected this application can be used to facilitate Lecturer in providing Semester Exam, increase knowledge and also make more practical test runs.

Keyword: Application, Exam, Website

\section{PENDAHULUAN}

Dalam perkembangan teknologi komputer, Jaringan atau koneksi- koneksi antar Jaringan juga semakin dibutuhkan untuk mempermudah pekerjaan user (pengguna) tentunya di dalam instansiinstansi tertentu. Koneksi jaringan biasa di gunakan untuk mengirim data, pengolahan data yang dapat didistribusikan, mencakup pemakaian database, software, Aplikasi dan peralatan hardware secara bersamaan. Koneksi antar Jaringan juga dapat membantu jalannya sebuah ujian atau tes online sehingga para peserta lebih mudah mengakses ujian atau tes lebih cepat tanpa membutuhkan alat bantu seperti kertas dan alat tulis.

Dunia informatika pun tak menutup kemungkinan untuk menerapkan konsep belajar untuk menjadikan seseorang ahli 
dalam penguasaan materi yang berkaitan dengan informasi teknologi. Fasilitas yang digunakan pada masa pembelajaran atau uji di era sebelum industri maju kebanyakan adalah dalam sebuah arsip lembar kerja kertas biasa. Zaman semakin maju dan teknologi semakin berkembang. Dimana-mana sudah hampir diterapkan sistem ujian berbasis online, dimana sistem ujian berbasis online tersebut secara keseluruhan memakai jasa website. Sebagai hal pembanding aplikasi ujian semester berbasis client server ini dapat juga di upload ke internet dan dapat juga dijalankan dalam lokal (tanpa koneksi internet). Dimana staf pengajar meng-input soal dengan jumlah yang diinginkan ke dalam server. Kemudian peserta (Client) akan mendapatkan soal secara otomatis berbasis web, maka jawaban dari siswa akan masuk dalam database jawaban yang nantinya akan diperiksa oleh staf pengajar.

Prodi Teknik Informatika masih menggunakan sistem ujian manual atau tidak menggunakan koneksi jaringan. untuk itu penulis mengajukan sebuah Aplikasi Ujian yang berbasis Web dengan menggunakan koneksi antar jaringan yaitu dengan sistem client-server. Sistem client server adalah sebuah sistem pembagian kerja antara sistem dan client yang mengakses server dalam suatu jaringan. Aplikasi ini dapat difungsikan untuk menambah pengetahuan dan juga membuat ujian berjalan lebih praktis.

\section{Rumusan Masalah}

Berdasarkan uraian latar belakang, maka penulis merumuskan masalah tentang bagaimana merancang Aplikasi Ujian Semester Pada Prodi Teknik Informatika berbasis Web, agar lebih mudah di gunakan dan praktis. penelitian ini di batasi, yaitu Aplikasi ini hanya berjalan pada saat ujian semester, 2. Pada proses Ujian dan pembuatan soal Ujian, 3. Soal - soal yang terdapat di dalamnya hanya Esay dan Pilihan Ganda, 4. Sistem yang di jalankan melalui sistem Client Server pada Prodi Teknik Informatika, sehingga mempermudah Dosen dalam memberikan Ujian pada Mahasiswa

\section{LANDASAN TEORI \\ Defenisi Sistem}

Untuk mendefenisikan sistem terdapat dua kelompok pendekatan yaitu pendekatan yang menekankan pada prosedurnya dan pendekatan yang menekankan pada komponen atau elemennya.

Pendekatan sistem yang lebih menekankan pada prosedur yaitu "sistem adalah suatu jaringan kerja dari prosedurprosedur yang saling berhubungan, berkumpul bersama-sama untuk melakukan suatu kegiatan atau menyelesaikan suatu kegiatan atau untuk menyelesaikan suatu sasaran tertentu." Sedangkan pendekatan sistem yang lebih menekankan pada elemen atau komponennya yaitu "sistem adalah kumpulan dari elemen-elemen yang berinteraksi untuk mencapai suatu tujuan tertentu." (Ladjamudin 2005).

\section{Klasifikasi Sistem}

Sistem merupakan suatu bentuk integrasi antara satu komponen dengan komponen yang lainnya. Karena sistem memiliki sasaran yang berbeda untuk setiap kasus yang terjadi yang ada didalam sistem tersebut. Menurut Al-barha bin ladjamudin (2005):

1. Sistem diklasifikasikan sebagai sistem abstrak (abstrak system) dan sistem fisik (phisical system). Sistem abstrak adalah sistem yang berupa pemikiran

\section{2}


atau ide-ide yang tidak tampak secara fisik, misalnya : sistem teologia, yaitu sistem yang berupa pemikiranpemikiran hubungan antara manusia dan tuhan. Sedangkan sistem fisik merupakan sistem yang ada secara fisik, misalnya sistem komputer, sistem akuntansi dan sebagainya .

2. Sistem diklasifikasikan sebagai sistem alamiah (natural system) dan sistem buatan manusia (human made system). 10 Sistem alamiah adalah sistem yang terjadi melalui proses alam, tidak dibuat manusia, misalnya : perputaran bumi mengelilingi matahari. Sedangkan sistem buatan manusia adalah sistem yang dirancang oleh manusia. Sistem buatan manusia yang melibatkan interaksi antara manusia dengan mesin disebut human machine system, misalnya : sistem informasi.

3. Sistem diklasifikasikan sebagai sistem tertentu (deterministik system) dan sistem tak tertentu (probabilistik system). Sistem tertentu adalah sistem yang beroperasi dengan tingkah laku yang sudah dapat diprediksi, misalnya : sistem komputer. Sedangkan sistem tak tentu adalah sistem yang kondisi masa depannya tidak dapat di prediksi karena mengandung unsur probabilitas.

4. Sistem diklasifikasikan sebagai sistem tertutup (closed system) dan sistem terbuka (open system). Sistem tertutup merupakan sistem yang tidak berhubungan dan tidak terpengaruh dengan lingkungan luarnya. Sedangkan sistem terbuka adalah sistem yang berhubungan dan terpengaruh dengan lingkungan luarnya.

\section{Pengertian Web}

Www atau world wide web atau web saja merupakan sebuah sistem yang saling terkait dalam sebuah dokumen yang berformat hypertext yang berisi beragam informasi, baik tulisan, gambar, suara, video, dan informasi multimedia lainnya dan dapat diakses melalui sebuah perangkat yang disebut web browser. Untuk menterjemahkan dokumen dalam bentuk hypertext ke dalam bentuk dokumen yang bisa dipahami, maka web browser melalui web client akan membaca halaman web yang tersimpan disebuah web server melalui protokol yang biasa disebut http atau Hypertext Transfer Protocol

\section{Defenisi Client - Server}

Menurut Budhi Irawan (2005): istilah client, server dan client/server dapat digunakan untuk merunjuk kepada konsep yang sangat umum atau hal spesifik dari perangkat keras atau perangkat lunak. Pada level yang sangat umum, sebuah client adalah setiap komponen dari sebuah sistem yang meminta layanan atau sumber daya (resources) dari komponen sistem lainnya. Sedangkan sebuah server adalah setiap komponen sistem yang menyediakan layanan atau sumber daya ke komponen sistem lainnya.

Server adalah komputer yang menyediakan fasilitas bagi komputerkomputer lain didalam jaringan dan client adalah komputer-komputer yang menerima atau menggunakan fasilitas yang disediakan oleh server. Server dijaringan tipe client-server disebut dengan Dedicated Server karena murni berperan sebagai server yang menyediakan fasilitas kepada workstation dan server tersebut tidak dapat berperan sebagai workstation. Sistem client-server biasanya berjalan pada setidaknya dua 
sistem yang berbeda. Satu komputer bertindak sebagai client dan lainnya sebagai server, tetapi client dan server juga bisa berada pada satu sistem komputer. Biasanya sebuah server melayani beberapa komputer client walaupun mungkin juga hanya melayani satu client.

Fungsi client-server biasanya dilakukan oleh file server, kecuali apabila dibutuhkan kinerja yang maksimal maka digunakanlah server yang khusus. Client biasanya berupa komputer desktop yang terhubung dalam jaringan. Apabila pemakai ingin mengambil atau menyimpan informasi bagian aplikasi client akanmengeluarkan permintaan yang akan dikirim ke server, server kemudian menjalankan permintaan dan mengirimkan informasi kepada client.

\section{Joomla}

Joomla merupakan web berbasis CMS yang bersifat Open Source. Joomla dibuat dengan bahasa pemrograman php dan membutuhkan database mySQL untuk menyimpan data. Karena dibuat dengan bahasa php, maka dibutuhkan interpreter php yang terinstal di web server untuk menjalankan Joomla Disamping itu juga dibutuhkan server database mySQL untuk penyimpanan data Joomla. Pada dasarnya, Joomla terdiri dari dua bagian. Yaitu halaman Front End dan halaman Back End. Halaman Front End merupakan halaman yang tidak memerlukan login dan bersifat public. Biasanya berisi halaman utama, artikel, dan sebagainya. Halaman ini dapat diakses oleh semua. Joomla mempunyai beberapa direktori yang mempunyai fungsi tersendiri. Setiap direktori mempunyai subdirektori dan filefile pendukung sesuai fungsinya. Berikut ini adalah struktur direktori Joomla 1.5.12
1. Administrator, ini merupakan direktori khusus administrator untuk keperluan pengelolaan website Joomla. Mulai dari proses installasi modul, komponen, plugin, bahasa sampai dengan proses maintenance web secara keseluruhan.

2. Cache, sebuah direktori khusus yang berfungsi untuk menyimpan data sementara di computer pengguna, tujuannya adalah mempercepat proses loading web jika dibuka pada waktu lain fungsinya sama dengan memori RAM komputer.

3. Components, merupakan direktori tempat menyimpan seluruh komponen yang terinstall di website Joomla.

4. Editor, sebuah direktori yang berfungsi untuk menyimpan berbagai editor yang diinstall pada website Joomla.

5. Help, sebuah direktori khusus untuk menampilkan bantuan jika kita menemukan Kendala dalam menggunakan Joomla.

6. Images, adalah direktori tempat menampung file-file gambar dan multimedia guna keperluan website Joomla.

7. Includes, ini merupakan direktori pendukung bagi aplikasi joomla yang lainnya.

8. Installation, direktori yang digunakan dalam proses installasi website Joomla. Jika proses installasi selesai, direktori ini sebaiknya dihapus, untuk keamanan web dimasa datang.

9. Language, sebuah direktori khusus untuk menampung jenis-jenis bahasa yang dapat digunakan di website yang multi bahasa.

10. Plugins, sebuah direktori untuk menampung tool tambahan dari Joomla, Misalnya, mos images, mos pagebreak,dll. 
11. Media, sebuah direktori yang diperuntukkan untuk menyimpan dan meng-upload file-file ke dalam website Joomla, baik file gambar maupun teks.

12. Modules, tempat menyimpan modul-modul yang terinstal di website Joomla. Templates, tempat menyimpan semua template yang terinstal di website Joomla. Template berperan dalam desain atau tata letak sebuah web berbasis joomla

\section{Pengertian DFD}

Data Flow Diagram adalah suatu model logika data atau proses yang dibuat lebih mendetail dibanding diagram konteks yang diperbolehkan, bisa dicapai dengan mengembangkan diagram. Sisa diagram asli dikembangkan ke dalam gambaran yang lebih terperinci yang melibatkan tiga sampai Sembilan proses dan menunjukkan penyimpanan data dan aliran data baru pada level yang lebih rendah (Lukman, $11: 2011$ )

\section{ERD}

Pengertian ERD (Entity Relationship Diagram) Merupakan suatu midel untuk menjelaskan hubungan antar data dalam basis data berdasarkan suatu presepsi bahwa real word terdiri dari object-object tersebut. (Lukman, 17 : 2011)

\section{METODE PENELITIAN}

Dalam merancang sistem dibutuhkan data dan informasi untuk menganalisa terhadap perancangan sistem. Metode yang dilakukan adalah metode pengumpulan data yang ada dilapangan. Metode tersebut antara lain :

a. Wawancara (interview)

Wawancara merupakan mengumpulan data yang dilakukan dengan cara mengadakan tanya jawab secara langsung dengan pihak pihak yang berhubungan dengan permasalahan yang diteliti.

b. Pengamatan (observasi)

Merupakan pengumpulan data secara langsung terhadap objek permasalahan yang akan dibahas, yang bertujuan untuk mengetahui tahap-tahap Ujian Semester pada Prodi Teknik Informatika.

c. Studi pustaka

Dilakukan dengan cara mempelajari literature - literatur yang ada hubungannya dengan permasalahan yang diteliti.

\section{Analisa sistem yang berjalan}

Berdasarkan hasil penelitian yang dilakukan oleh penulis pada Prodi Teknik Informatika ternyata sistem yang digunakan pada saat Ujian masih bersifat offline yakni Mahasiswa mengisi jawaban dengan menggunakan alat bantu kertas dan alat tulis untuk menyelesaikan ujian dan juga butuh ketelitian para dosen untuk mengawasi jalannya ujian

\section{Analisys system yang di usulkan}

1. Sistem yang diusulkan yaitu sebuah sistem yang dirancang dengan menggunakan Aplikasi berbasis Web.

2. Mahasiswa atau peserta mendaftar terlebih dahulu sebelum mengikuti ujian.

3. Setelah itu admin mengkonfirmasi peserta atau mahasiswa setelah pendaftaran.

4. Kemudian Dosen login untuk membuat soal dan membuat akses soal pada mahasiswa yang telah terdaftar ataw yang telah di konfirmasi admin.

5. Mahasiswa login dan mengikuti ujian. 
6. setelah mahasiswa menyelesaikan ujian, dosen login untuk memberikan penilaian dan memberikan hasil ujian.

7. Mahasiswa atau peserta menerima hasil ujian.

\section{Analisis kebutuhan sistem}

Dalam mendukung pengembangan Aplikasi ujian semester berbasis web pada prodi Teknik Informatikan, perlu adanya dukungan hardware maupun software yang memadai. Sehingga pengembangan sistem yang akan dilakukan dapat menghasilkan sistem yang sesuai dengan kebutuhan yang ada. Identifikasi Perangkat Keras (Hardware) Adapun perangkat keras yang dibutuhkan dalam sistem adalah sebagai berikut:

1. Komputer Server

a. Processor Intel Pentium 4, $2.7 \mathrm{GHz}$ atau yang lebih tinggi

b. Memory yang dibutuhkan sebesar 1 GB, namun disarankan memory yang digunakan sebesar $2 \mathrm{~GB}$

c. Monitor mempunyai resolusi $1024 \mathrm{x}$ 768 pixels

d. Kapasitas ruang hardisk minimal 80 $\mathrm{Mb}$ atau yang lebih tinggi

e. Kabel UTP untuk di hubungkan ke komputer client

2. Komputer client

a. Processor Intel Pentium 4, $2.7 \mathrm{GHz}$ atau yang lebih tinggi

b. Memory yang dibutuhkan sebesar $128 \mathrm{MB}$, namun disarankan memory yang digunakan lebih besar

c. Monitor mempunyai resolusi $1024 \mathrm{x}$ 768 pixels

d. Kapasitas ruang hardiks minimal 80 $\mathrm{Mb}$ atau yang lebih tinggi

e. Kabel UTP untuk di hubungkan ke komputer server

Identifikasi Perangkat Lunak (Software)
Dalam perancangan Aplikasi Ujian Semester pada Prodi Teknik Informatika Berbasis Web, software yang akan digunakan adalah:

1. Sistem operasi Window 7 untuk komputer Server

2. Sistem operasi Windows 98 atau Windows Yang lebih tinggi untuk komputer Client

3. Program PHP

4. Program database Mysql

5. Program web server

6. Web Browser menggunakan Google chrome dan Mozila firefox

\section{PERANCANGAN SISTEM}

\section{Diagram Konteks}

Diagram konteks merupakan gambaran kasar aliran informasi dan data yang akan dilakukan oleh sistem yang akan dirancang. Diagram ini hanya menjelasakan secara umum gambaran aliran konteks dari rancangan sistem yang akan dibuat.

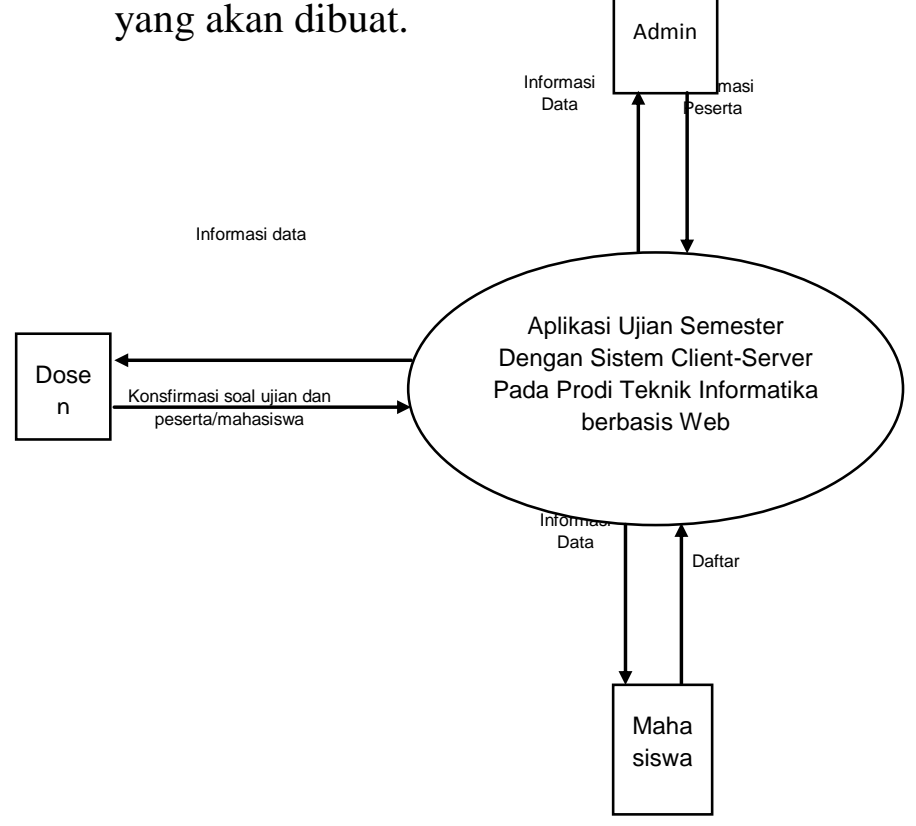

Gambar 1 : Diagram Konteks

\section{Diagram Flow Data (DFD) DFD Level 1}

DFD level 1 merupakan penjelasan lebih rinci terhadap proses-proses yang 
terjadi pada aplikasi. DFD level 1 memberikan gambaran yang lebih dan digambarkan pula penyimpan data dan proses yang terjadi di dalam aplikasi.

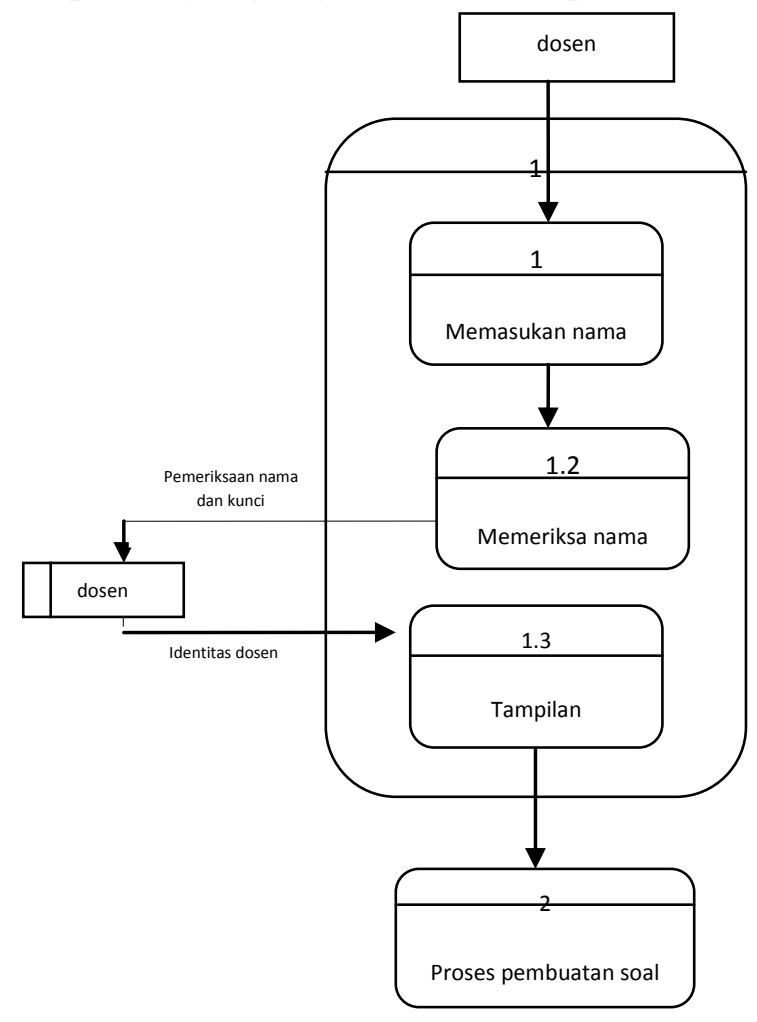

Gambar 2 : Diagram Level 1

\section{Entitas Relation Diagram (ERD)}

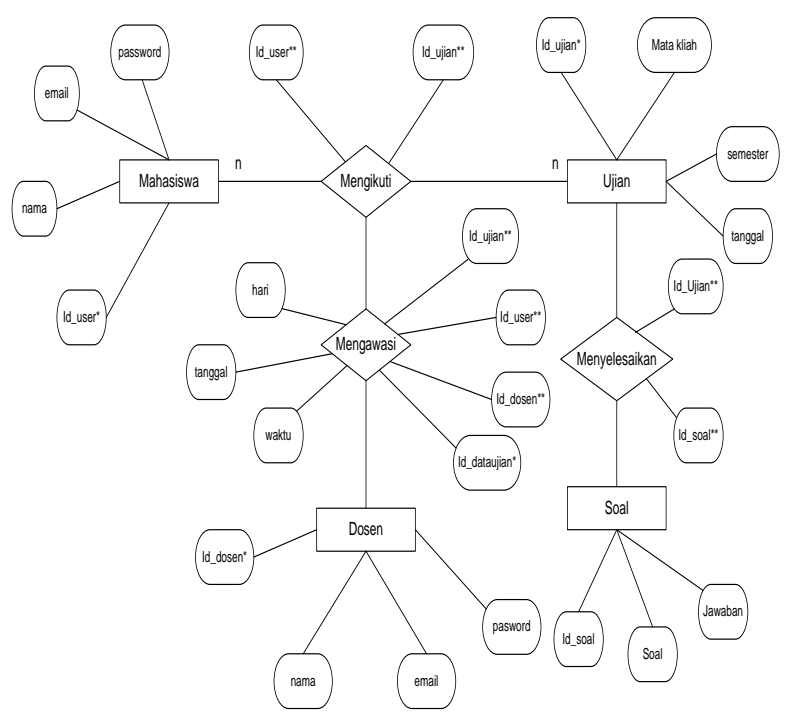

Gambar 3 : Entity Relationship Diagram

\section{Relasi Tabel}

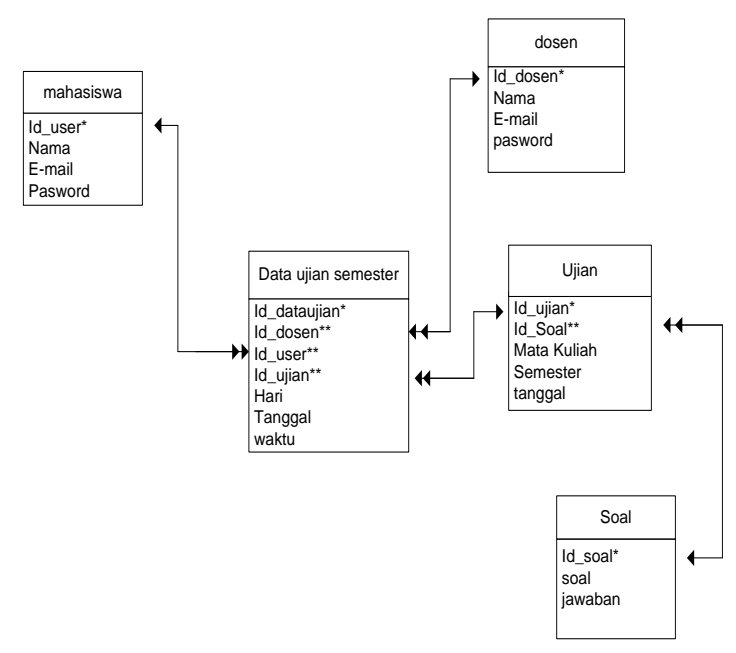

Gambar 4 : Relasi Tabel

\section{Perancangan Tabel}

Tabel 1 Tabel Mahasiswa

\begin{tabular}{|l|l|l|l|}
\hline \multicolumn{1}{|c|}{$\begin{array}{c}\text { Field } \\
\text { nama }\end{array}$} & Data type & Field size & Description \\
\hline$*_{\text {id_user }}$ & Int & 11 & Id_user \\
\hline Name & Varchar & 35 & Nama \\
\hline Email & Varchar & 50 & Email \\
\hline Password & Varchar & 50 & Password \\
\hline
\end{tabular}

Tabel 2 Tabel Ujian

\begin{tabular}{|l|l|l|l|}
\hline \multicolumn{1}{|c|}{$\begin{array}{c}\text { Field } \\
\text { nama }\end{array}$} & Data type & Field size & $\begin{array}{c}\text { Descripti } \\
\text { on }\end{array}$ \\
\hline *id_ujian & Int & 11 & Id_ujian \\
\hline $\begin{array}{l}\text { Matakulia } \\
\text { h }\end{array}$ & Varchar & 50 & $\begin{array}{l}\text { Matakulia } \\
\text { h }\end{array}$ \\
\hline Semester & Varchar & 12 & Semester \\
\hline Tanggal & Date & & Tanggal \\
\hline
\end{tabular}

Tabel 3 Tabel User Dosen

\begin{tabular}{|l|l|l|l|}
\hline \multicolumn{1}{|c|}{$\begin{array}{c}\text { Field } \\
\text { nama }\end{array}$} & $\begin{array}{c}\text { Data } \\
\text { type }\end{array}$ & $\begin{array}{c}\text { Field } \\
\text { size }\end{array}$ & Description \\
\hline *Id_dosen & Int & 11 & Id_dosen \\
\hline Nama & Varchar & 35 & Nama \\
\hline
\end{tabular}




\begin{tabular}{|l|l|l|l|}
\hline Email & Varchar & 50 & Email \\
\hline Password & Varchar & 50 & Password \\
\hline
\end{tabular}

Tabel 4 Data Ujian Semester

\begin{tabular}{|l|l|l|l|}
\hline $\begin{array}{l}\text { Field } \\
\text { nama }\end{array}$ & Data type & Field size & Description \\
\hline *id_ujian & Int & 11 & Id_dataujian \\
\hline Hari & Varchar & 15 & Hari \\
\hline Tanggal & Date & & Tanggal \\
\hline Waktu & Varchar & 15 & Waktu \\
\hline
\end{tabular}

Tabel 5 Tabel Soal

\begin{tabular}{|l|l|l|l|}
\hline $\begin{array}{r}\text { Field } \\
\text { nama }\end{array}$ & Data type & Field size & $\begin{array}{c}\text { Descripti } \\
\text { on }\end{array}$ \\
\hline *id_Soal & Int & 11 & Id_Soal \\
\hline Soal & Varchar & 500 & Soal \\
\hline Jawaban & Varchar & 500 & Jawaban \\
\hline
\end{tabular}

\section{IMPLEMENTASI SISTEM}

\section{Tempilan Halam Utama}

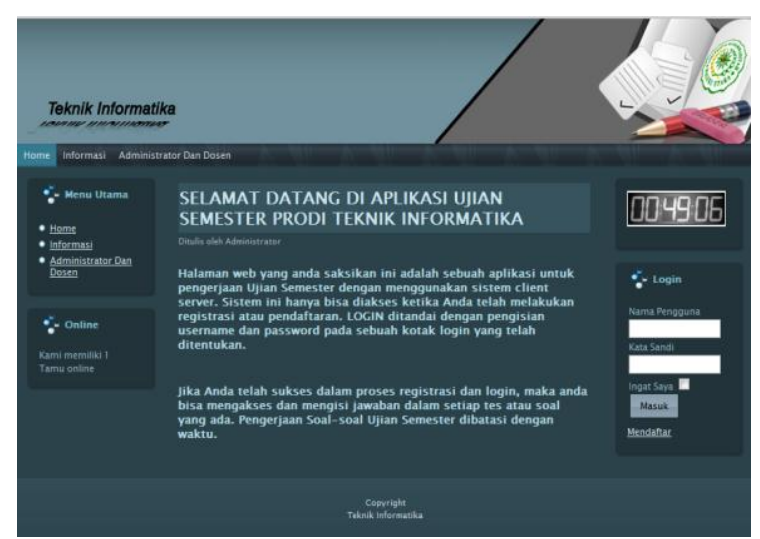

Gambar 5 : Halaman Utama

\section{Form Informasi}

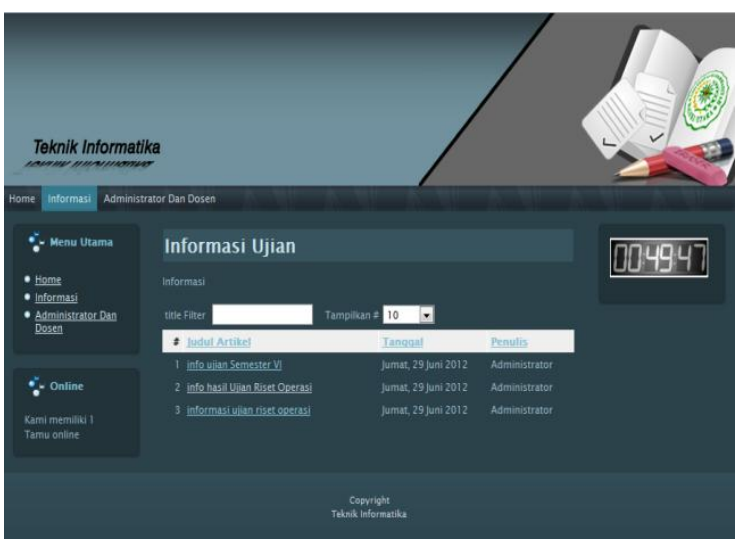

Gambar 6 : Form Informasi

\section{Form Administrator Dan Dosen}

\section{Teknik hiomatillia}

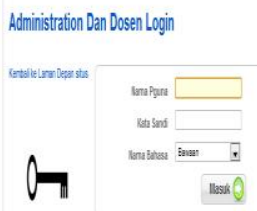

Gambar 7 : Form Admin dan Dosen

\section{Form Login mahasiswa}

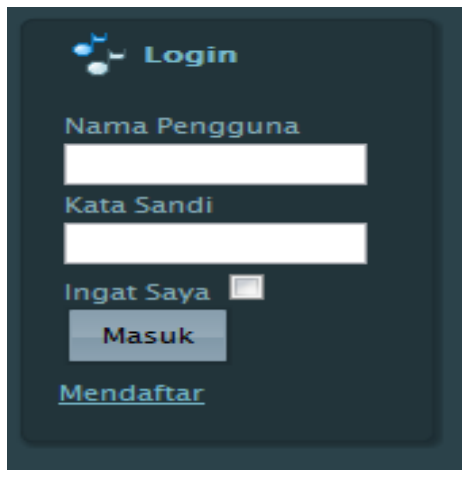

Gambar 8 : Form Login mahasiswa

\section{Tampilan form pendaftaran}




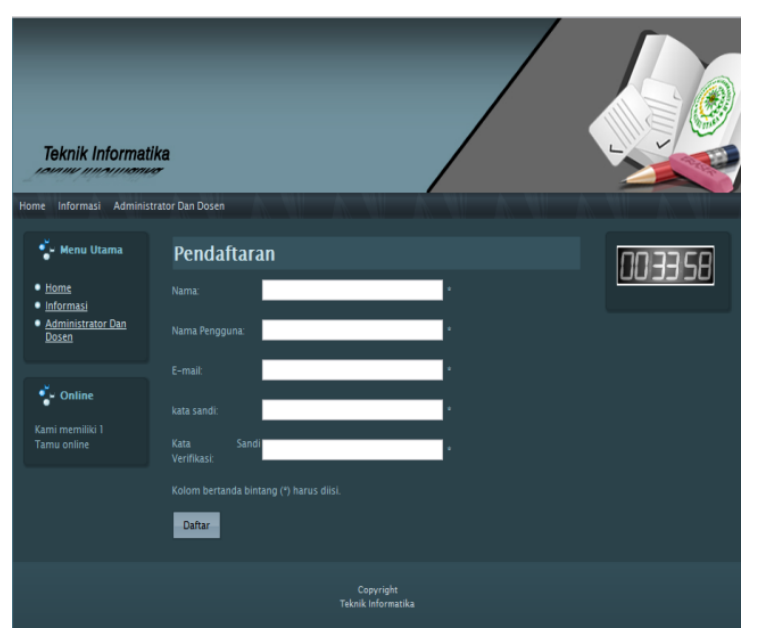

Gambar 9 : Form Pendaftaran

\section{Proses mengakses soal dengan login user}

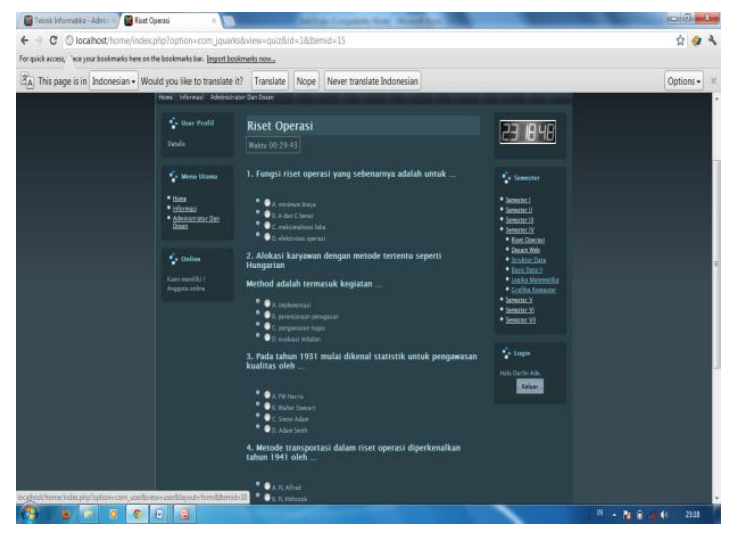

Gambar 10 : Soal Ujian

\section{Hasil ( Sesions )}

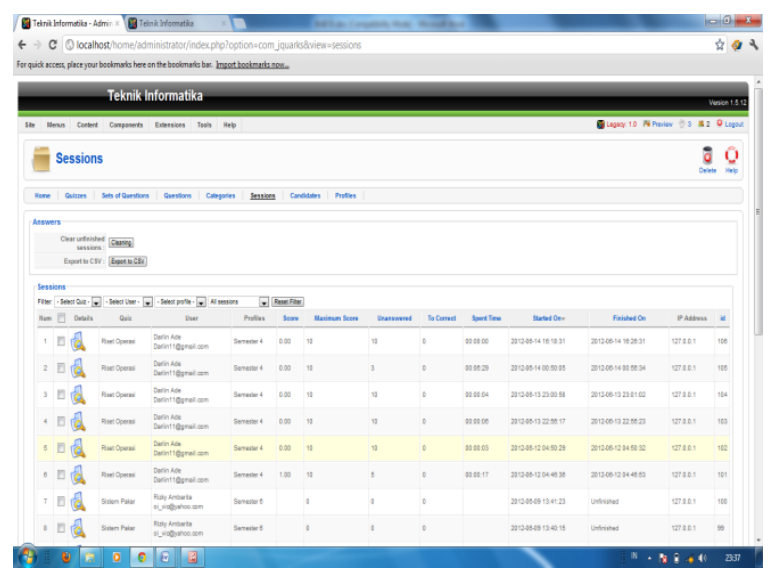

Gambar 11 : Form Hasil yang sudah diikuti user atau mahasiswa

\section{KESIMPULAN}

1. Aplikasi Ujian Ini menjadi salah satu solusi yang dapat di gunakan untuk membuat jalannya ujian semester menjadi lebih efesien tetapi bukan sebagai pengganti Sistem ujian yang lama. 2. Menggunakan Aplikasi Ujian Berbasis Web dengan Distem Client Server ini sangatlah mudah di akses oleh peserta untuk mengikuti ujian semester.

Dengan adanya aplikasi ini di harapkan dapat menambah pengetahuan bagi mahasiswa pada prodi teknik informatika Berdasarkan kesimpulan di atas, maka diajukan saran sebagai berikut.: 1. dapat menerapkan Sistem untuk mempermudah Dosen memberikan Ujian pada Prodi Teknik Informatika : 2. dapat di jadikan sebagai acuan untuk menciptakan suatu aliran formasi yang baru secara sistematis dan terintegrasi yang dapat di susun menjadi sebuah sistem yang terpadu

\section{DAFTAR PUSTAKA}

Al-Bahra, Bin Ladjamudin, Analisis dan Desain Sistem Informasi, Penerbit Graha Ilmu, Yogyakarta. 2005.

Andi Setiawan, Ade Irma, P.S. 2006. Pengolahan Database MySQL dengan Script PHP. Bandung : CV. YRAMA WIDYA

Al Fatta Hanif, Analisis \& Perancangan Sistem Informasi, Yogyakarta : Andi, 2007

Nugroho, Bunafit. 2008. Latihan Membuat Aplikasi Web PHP dan MySQL dengan Dreamweaver $M X$ $(6,7,2004)$ dan 8. Cetakan ke-1 Jogjakarta : Gava Media

Tim EMS, 2011, Proyek Membuat Website Dengan Joomla,Penerbit PT. Elex Media Komputindo, Jakarta 
Arsitektur Client Server. http:// achmad89. wordpress. com, 25 Mei 2012

Kelebihan Dan Kekurangan Peer to peer dan Client Server, http://ilmu Komputer. com, 24 Mei 2012

Instalasi jaringan client - server. http:// akupekuk. blogspot. com. $25 \mathrm{Mei}$ 2012

Membuat Web Dengan Joomla. http:// ilmukomputer.com. 22 Mei 2012

Zuraida Septia Nurlaili Sistem Informasi Penilaian Siswa SMA Negeri 1 Wonosari Kabupaten Klaten.Tugas Akhir. Universitas Sebelas Maret. (2007).

Miftahul Huda Ngadirojo, Pembangunan Sistem Informasi Pengolahan Data Nilai Siswa Berbasis Web Pada Sekolah Menengah Kejuruan (SMK), IJNS - Indonesian Journal on Networking and Security Volume 3 No 2- 2014, ISSN: 23025700 (Print) 2354-6654 (Online)

Nursahid, Berliana Kusuma Riasti, Bambang Eka Purnama, Pembangunan Sistem Informasi Penilaian Hasil Belajar Siswa Sekolah Menengah Atas (SMA) Negeri 2 Rembang Berbasis Web, IJNS - Indonesian Journal on Networking and Security - Volume 4 No 2 - 2015, ISSN : 2302-5700 (Print) - 2354-6654 (Online) 